\title{
Container Shipping And Ports: An Overview
}

\author{
THEO E. NOTTEBOOM*
}

Institute of Transport and Maritime Management Antwerp (ITMMA), University of Antwerp

\begin{abstract}
Globalisation, deregulation, logistics integration and containerisation have reshaped the port and shipping industry. Port and maritime companies are challenged to redefine their functional role in the value chain for the sake of creating customer value and of ensuring the survival and growth of the company. Companies are busily trying to disrupt the status quo rather than preserve it. Based on empirical evidence, this paper demonstrates that because of the rapidly changing environment the port and liner shipping markets are not stable any longer. Individual terminal operators and shipping lines tend to walk different paths on a quest for higher margins and increased customer satisfaction. And more than once they (have to) change paths.
\end{abstract}

\section{Introduction}

The market environment in which container ports and shipping lines are operating is substantially changing. One of the main driving forces to change emerges from the globalisation process and the large-scale adoption of the container since the late 1960s. Worldwide container port throughput increased from 36 million TEU $^{1}$ in 1980 to 266 million TEU in 2002. Forecasts point to between 432 and 468 million TEU in 2010 (OSC, 1997 and OSC, 2003). While the Atlantic Rim is the cradle of containerisation, economically dynamic East Asia has become the world's main container region. The share of Asia in worldwide container port throughput rose from 25 per cent in 1980 to about 46 per cent now, while Europe saw its share drop from 32 per cent to 23 per cent.

The rise of world containerisation is the result of the interplay of macroeconomic, microeconomic and policy-oriented factors. World trade is facilitated through the elimination of trade barriers and the liberalisation and deregulation of markets. Practical evidence shows that the public sector has redefined its role in the port and shipping industries through privatisation and corporatisation schemes. Contemporary government intervention in an efficiency-oriented industry typically focuses on the issue of market liberalisation and the creation of a level playing field for fair competition, the monopoly issue and the public goods issue (see Goss, 1990; Baird, 2000; De Monie, 1995; Notteboom and Winkelmans, 2001 and Everett, 1996). With the reassessment of the role of

\footnotetext{
* ITMMA, University of Antwerp, Keizerstraat 64, 2000 Antwerp (Belgium). E-mail: theo.notteboom@ua.ac.be

${ }^{1}$ TEU $=$ twenty-foot equivalent unit, a standard container with a length of 20 '.
} 
the government much attention is now paid to governance issues in ports and shipping (see Brooks, 2001 and Wang, 2003).

Market liberalisation revealed to enhance the development of logistics throughout the world. International supply chains have become complex and logistics models evolve continuously as a result of influences and factors such as the globalisation and expansion into new markets, mass customisation in response to product and market segmentation, lean manufacturing practices and associated shifts in costs. Customers' need for a wider array of global services and for truly integrated services and capabilities (design, build and operate) triggered integrated logistics strategies (Christopher, 1992 and McKinnon, 2001) and a shift from transportation-based 3PLs (Third Party Logistics) to warehousing and distribution providers and at the same time opened the market to innovative forms of nonasset related logistics service provision, that is 4PL (Fourth Party Logistics) ${ }^{2}$.

Intensified competition at the supply side creates pressures on cost management and on margins. The evolutions in supply chains and logistics models urge container ports and shipping lines to re-think their function in the logistics process. Recent literature has addressed the impact of changes in logistics on the functional role of ports and shipping in value chains. Robinson (2002) places the role of seaports within a new paradigm of ports as elements in value-driven chain systems. Notteboom and Winkelmans (2001b) and Heaver et al (2000) primarily discussed the changing role of port authorities in the new logistic-restructured environment, while Martin and Thomas (2001) addressed structural changes in the container terminal community. Slack et al (2002) demonstrates how the organisational restructuring of the container shipping industry is taking place against the backdrop of logistics.

This paper aims to provide an overview of the challenges facing port and maritime companies in an ever-changing competitive environment. Based on empirical evidence, the paper analyses the paths shipping lines and terminal operating companies are walking in the hope to face the ongoing dynamics in the highly competitive container and logistics markets in a sustainable manner.

\section{How do container shipping lines cope with the changing market environment?}

\subsection{Instability in liner shipping}

In the first ten years of containerisation lines rarely had to worry about profitability. Consortia managed service patterns and capacity for specific trade routes and powerful liner conferences ${ }^{3}$ looked after freight rates, that is through revenue pooling agreements

\footnotetext{
${ }^{2}$ Whereas a 3PL service provider typically invests in warehouses and transport material, a 4PL service provider restricts its scope to IT-based supply chain design. Consultants and IT shops help 3PLs and 4PLs to expand into new markets and to become full-service logistics providers.

${ }^{3}$ A liner conference is defined by Unctad's Convention on a Code of Conduct for Liner Conferences (Chapter 1) as 'a group of two or more vessel-operating carriers which provides international liner services for the carriage of cargo on a particular route or routes within specified geographical limits and which has an agreement or arrangement, what-ever its nature, within the framework of which they operate under uniform or common freight rates and any other agreed conditions with respect to the provision of liner services.'
} 
based on conference tariffs. These structures endured until the middle of the 1980s when non-conference operator Evergreen began to challenge the existing situation.

Over the last decade container carriers have significantly under performed financially compared to other industries. The weaker performance can be related to the combination of the capital-intensive operation and the high risks associated with the revenues. Shipping remains a very capital-intensive industry where some assets are owned and other are leased and there exists a wide variability in cost bases. These explain the short-term instability in the industry (Brooks, 2000).

Economic forces tend to push freight rates down. Economies of scale lead to surplus space onboard of the vessels that lines are eager to fill. Existing slot overcapacity in some trades made freight rates tumble down, neutralizing the achieved cost reductions. A lot of carriers ended up with smaller margins and lower return on investment. The carrier will reach a reasonable profitability when trade volume is close to or exceeds the capacity provided. Controlling capacity to match demand seems logical, but hard to accomplish. Lines vie for market share and capacity tends to be added as additional loops, that is in large chunks. Capacity management remains very challenging until this fragmented industry looks more like an oligopoly. The boom in the Asia trades in 1999-2000 followed by a decline in 2001-2002 provides a good illustration. Capacity in the boom was very highly utilised. Soaring demand made shipping lines to implement large rate increases in these trades against only token resistance by shippers. When trade growth began to turn down, an event that unfortunately coincided with the introduction of new tonnage, the position went swiftly into reverse.

Lines operate regular, reliable and frequent services and incur high fixed costs. Once the large and expensive networks are set up, the pressure is on to fill them with freight. The simple observation that unused capacity cannot be stored and used later further increases the pressure to go for volume. In order to secure cargo, shipping lines have negotiated long-term contracts with shippers, however the risk balance in these contracts resides at the carrier side. In an environment of overcapacity, high fixed costs and product perishability, lines will chase short run contribution filling containers at a marginal cost only approach, often leading to direct operational losses on the trades considered.

Rate erosion would not be that bad if changes in freight prices had a major impact on demand. Unfortunately, for most shipments freight revenue only accounts for a very small portion of the shipment's total value, but as carriers cannot influence the size of the final market, they will try to increase their short run market share by reducing prices. As such, shipping lines may reduce freight rates without substantially affecting the underlying demand for container freight.

Rather inelastic demand curves are the core problem for liner profitability and are at the heart of liner strategy. Lines have come to accept that they have to take whatever price is offered in the market. This acceptance has, in turn, led to intense concentration on costs.

\subsection{Scale increases in vessel size}

Throughout the 1990s a great deal of attention was devoted to larger, more fuel-economic vessels and this indeed produced substantial reductions in cost per TEU of capacity provided (table 1). Larger ships typically have a lower cost per TEU-mile than smaller units with the same load factor. Samsung demonstrated that a vessel of 12000 TEU on the Europe - Far East route would generate a 11 per cent cost saving per container slot compared to a 8000 TEU vessel and even 23 per cent compared to a 4000 TEU unit. 
Similar calculations made by Drewry for the trans-Pacific route point to potential cost differences of around 50 per cent between a panamax unit of 4000 TEU and a mega postpanamax unit of 10000 TEU (Drewry, 2001). Cullinane et al (1999) have demonstrated that economies of scale for the trans-Pacific and Europe - Far East routes are enjoyed at ship sizes beyond $8000 \mathrm{TEU}$, even if one considers different scenarios as regards port productivity. The optimal size for the trans-Atlantic liner route would range between 5000 and 6000 TEU.

\begin{tabular}{lrrrrrrrr}
\hline & Jan 1991 & \multicolumn{1}{c}{ Shares } & Jan 1996 & Shares & Jan 2001 & Shares & Jan 2006 & Shares \\
\hline >5000 TEU & 0 & $0.0 \%$ & 30648 & $1.0 \%$ & 621855 & $12.7 \%$ & 2355033 & $30.0 \%$ \\
4000/4999 TEU & 140032 & $7.5 \%$ & 428429 & $14.4 \%$ & 766048 & $15.6 \%$ & 1339978 & $17.1 \%$ \\
$3000 / 3999$ TEU & 325906 & $17.6 \%$ & 612377 & $20.6 \%$ & 814713 & $16.6 \%$ & 892463 & $11.4 \%$ \\
2000/2999 TEU & 538766 & $29.0 \%$ & 673074 & $22.6 \%$ & 1006006 & $20.5 \%$ & 1391216 & $17.7 \%$ \\
1500/1999 TEU & 238495 & $12.8 \%$ & 367853 & $12.3 \%$ & 604713 & $12.3 \%$ & 719631 & $9.2 \%$ \\
1000/1499 TEU & 329578 & $17.7 \%$ & 480270 & $16.1 \%$ & 567952 & $11.6 \%$ & 596047 & $7.6 \%$ \\
500/999 TEU & 191733 & $10.3 \%$ & 269339 & $9.0 \%$ & 393744 & $8.0 \%$ & 438249 & $5.6 \%$ \\
100/499 TEU & 92417 & $5.0 \%$ & 117187 & $3.9 \%$ & 132472 & $2.7 \%$ & 114976 & $1.5 \%$ \\
\hline TOTAL & 1856927 & $100.0 \%$ & 2979177 & $100.0 \%$ & 4907503 & $100.0 \%$ & 7847593 & $100.0 \%$ \\
\hline
\end{tabular}

Table 1: Scale increases in vessel size: evolution of the world cellular fleet 1991-2006

Note: Projection at January 2006 as compiled with existing fleet and order book as at 15 June 2003

Source: BRS Alphaliner Fleet Report, September 2003

However, there are several reasons why a unilateral focus of carriers on vessel sizes does not lead to a more stable market environment.

First of all, the economies of scale did not necessarily translate into reductions in cost per TEU carried. Hence, overall vessel and voyage costs have been increased dramatically in order to establish competitive networks satisfying the global requirements of the shippers. Carriers need a lot of vessels of similar size to ensure a weekly departure at each port of call (that is 12 vessels for a pendulum service Europe -Far East - US West Coast, 8 vessels for a Europe - Far East service and 4 to 5 vessels for a trans-Atlantic service). Upgrading the vessel size on a specific route takes several years and demands huge investments.

Secondly, given that there seem to be no technical reasons preventing containerships from getting larger, it will be economic and operational considerations that will act as the ultimate barrier on post-panamax vessel sizes and designs of the future. Although some shipping lines are now looking into the possibility of deploying vessels of more than 9,000 TEU, it is expected that this vessel size will not become the general rule in the next 10 years. There are strong indications that the range of 5,500 to 6,500 TEU will reveal to be the most competitive vessel size for the time being as these ships offer more flexibility in terms of the number of potential ports of call and consequently the direct access to specific regional markets.

Thirdly, the recent scale enlargement in vessel size has reduced the slot costs in container trades, but carriers have not reaped the full benefits of economies of scale at sea (Lim, 1998). Poorer slot utilization and the need to go out and buy more cargo at lower 
rates can have a profound impact on carriers' revenues and lead to lower profitability. The ultra-large container ships can be deployed efficiently on the major trade lanes, provided they are full. However, many carriers have not been able to realize a continuous high utilization of available slot capacity on their bigger vessels. Unpredictable business cycles on the major trade lanes result in unstable cargo guarantees to shipping lines (even if service contracts are quite common).

Fierce price competition leaves the entire liner shipping industry worse off in terms of profitability. Graham (1998) rightly stated that cost cutting practices through consecutive rounds of post-panamax newbuildings is not helping to reach stability in liner shipping. The danger of enhancing a vicious cycle towards further scale increases, overbuilding and falling margins is eminently clear. Adding post-panamax capacity can give a short-term competitive edge to the early mover, putting pressure on the followers in the market to upgrade their container fleet and to avert a serious unit cost disadvantage. A boomerang effect eventually also hurts the carrier who started the price war.

\subsection{Co-operation, mergers and acquisitions}

The further decrease in unit cost per TEU-mile can only be achieved safely - that is without enhancing destructive competition - by combining the deployment of bigger vessels with an organisational scale increase (Chinnery, 1999). Horizontal integration in liner shipping comes in three forms: trade agreements such as liner conferences, operating agreements (that is vessel sharing agreements, slot chartering agreements, consortia and strategic alliances) and mergers and acquisitions. The top 20 carriers controlled 26 per cent of the world slot capacity in 1980, 41.6 per cent in 1992 and about 58 per cent on 2003 (see also table 2). More important than which carriers are in the top 20 is the fact that only few container carriers outside the top 20 operate post-panamax vessels ${ }^{4}$ and that most of the top 20 carriers are involved in multi-trade strategic alliances.

Figure 1 underlines the dynamics in strategic alliance formation and in mergers and acquisitions in liner shipping ( P\&O Nedlloyd in 1997, Maersk SeaLand in 1999). The long list of acquisitions of CP Ships (that is Lykes Lines, TMM, etc.) is not included. The economic rationality for mergers and acquisitions is rooted in the objective to size, growth, economies of scale, market share and market power. Other motives for mergers and acquisitions in liner shipping relate to gaining instant access to markets and distribution networks, obtaining access to new technologies or diversifying. Acquisitions typically feature some pitfalls, certainly in the highly international maritime industry: cultural differences, overestimated synergies and expense of acquisition. Still, acquisitions make sense in liner shipping as the maritime industry is mature and the barriers to entry are relatively high (due to investment volumes required and customer base development). It provides an alternative when a shipping line is unwilling to accept the costs and risks of entering new venturing.

\footnotetext{
${ }^{4}$ A post-panamax vessel is a vessel too large to pass through the Panama Canal. The critical maximum vessel dimensions on the Panama Canal are $32.31 \mathrm{~m}$ wide, $294.13 \mathrm{~m}$ length overall (LOA) and a draft of $12.04 \mathrm{~m}$. These maximum dimensions are based on the capacity of existing lock systems.
} 


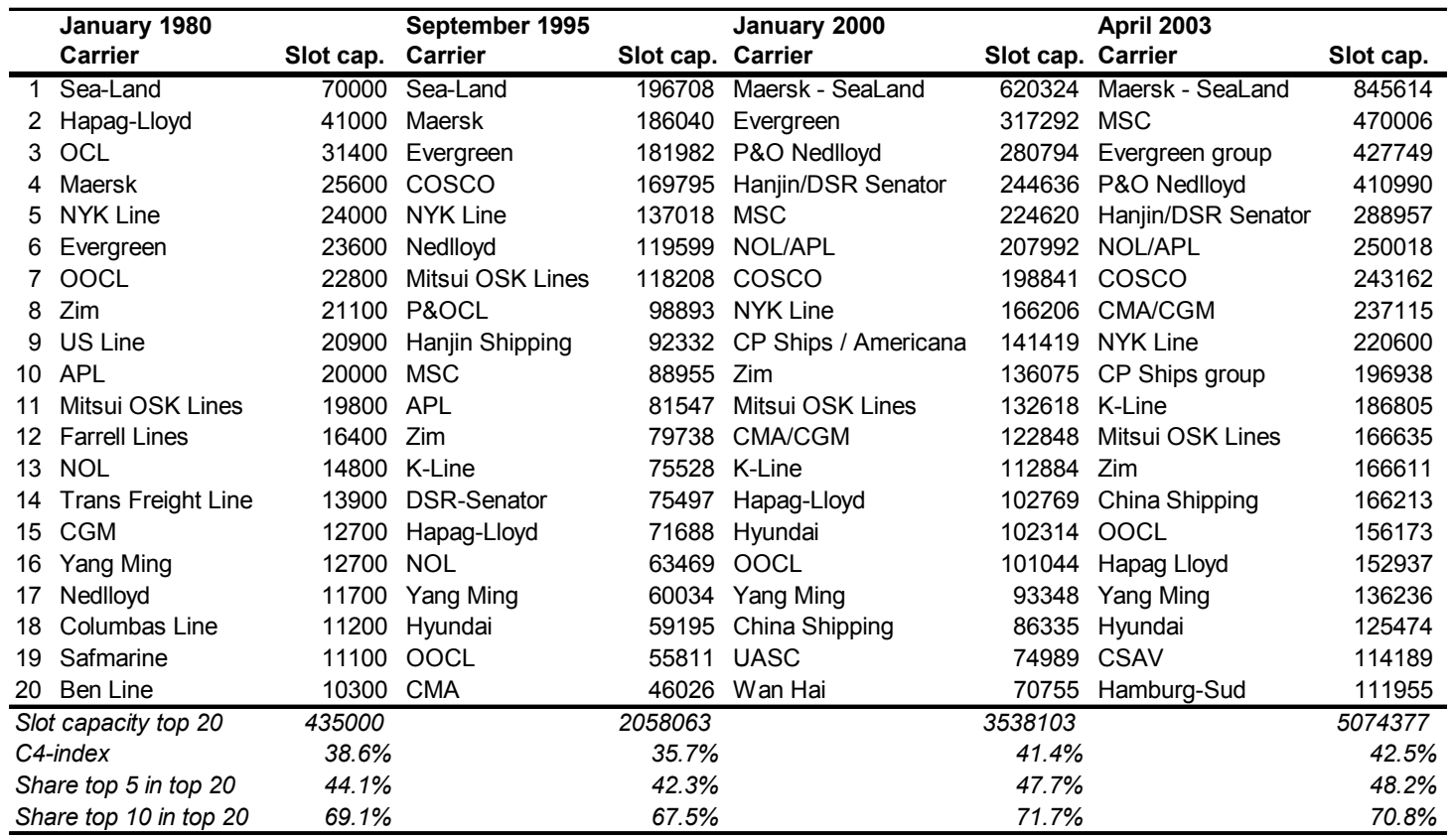

Table 2: Slot capacity operated by the top twenty carriers

Source: compiled from BRS Alphaliner and Containerisation International.

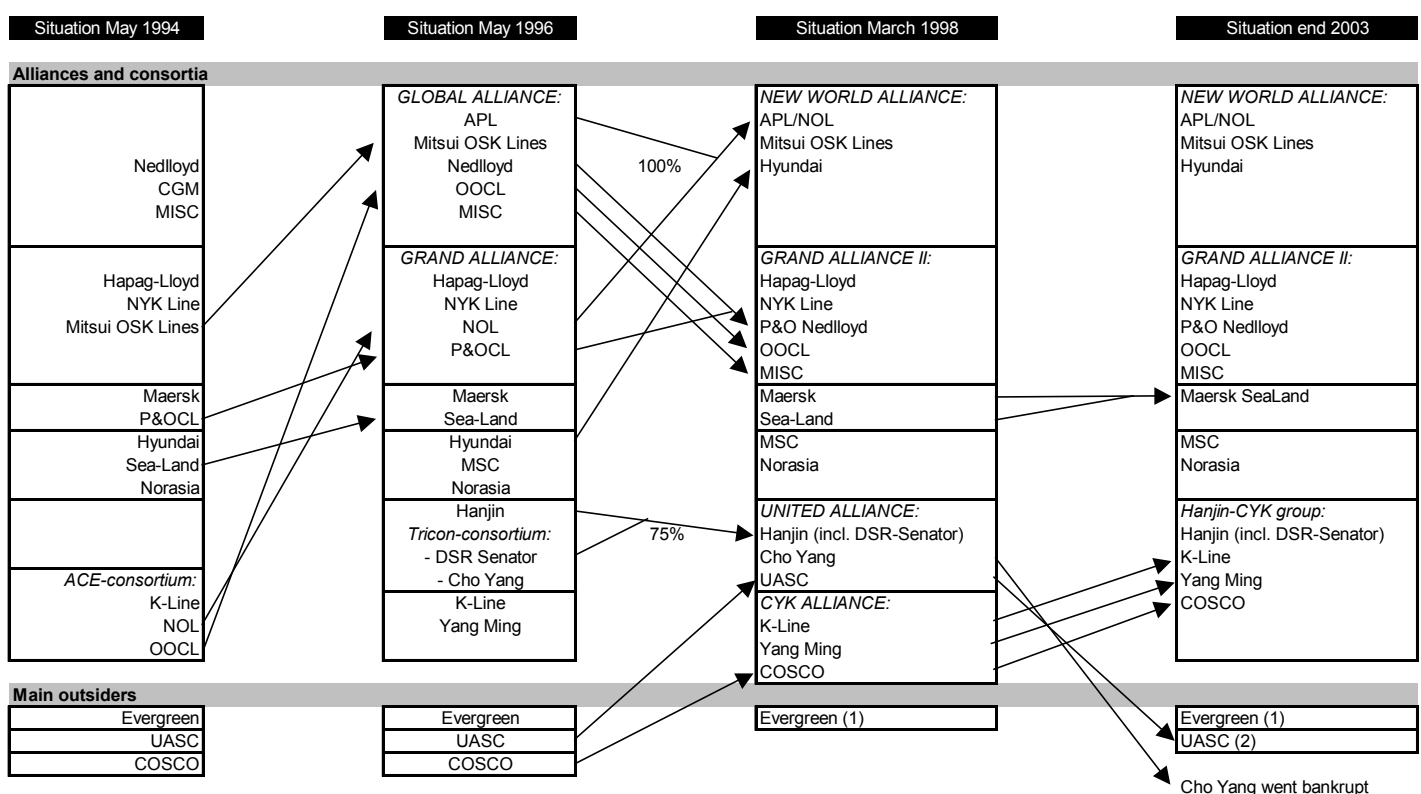

Figure 1: M\&A and strategic alliances on the trade Europe - Far East (Source: ITMMAUA)

Note: the main mergers and acquisitions are shown on this figure by the joining arrows

Co-operation is likely to be advantageous when the combined costs of operations or buying transactions (such as negotiating and contracting) are lower than the cost of 
operating alone. Co-operation between carriers serves as a means to secure economies of scale, to achieve critical mass in the scale of operation and to spread the high level of risk associated with investments in ships (Ryoo and Thanopoulou, 1999 and Slack et al, 2002). Carriers are viewing market mass as one of the most effective weapons in coping with a trade environment that is characterized by intense pricing pressure. Alliances provide its members easy access to more loops or services with relative low cost implications and allow them to share terminals, to co-operate in many areas at sea and ashore, thereby achieving costs savings in the end. Midoro and Pitto (2000) and Graham (1998) argue that despite these advantages of alliance formation, strategic alliances in itself have not become a stabilizing factor in liner shipping due to the organizational complexity of the alliance and perceived intra-alliance competition that undermines trust between carriers involved. Mergers and acquisitions have reduced the number of partners in alliances (figure 1), but the lack of differentiation of the partners' roles and the absence of co-ordination of marketing and sales still prevent the alliance structure from playing a key role in the alleviation of market instability.

\subsection{Landside logistics as a revenue base, cost control centre and a source of differentiation}

In a shipping industry already dominated by large vessels, mergers/acquisitions and strategic alliances the potential cost savings at sea still left are getting smaller and the pressure to find cost savings elsewhere is growing. Inland logistics is one of the most vital areas still left to cut costs. More economical ships and alliance co-operation have lowered ship system costs, but at the same time intermodal costs share an increasing part of the total cost. In a typical intermodal transport, inland transport now accounts for a much larger component of the cost than running the vessel. The portion of inland costs in the total costs of container shipping would range from 40 per cent to 80 per cent. For instance, Hastings (1997) reports that the inland costs for CP Ships account for 42 per cent of its overall costs or even 50 per cent if the repositioning of empty containers is included. For $\mathrm{P} \& \mathrm{O}$ Nedlloyd inland transportation would account for 70 per cent of total cost.

The shift of balance from vessel costs to landside costs is enhanced by transport price evolutions. Overcapacity keeps a limit on ocean pricing, while inland pricing is much more cost-driven. As such, cost increases in inland moves tend to pass through to price levels more easily compared to ocean moves, thereby increasing the absolute difference between both items. In general the price difference per TEU-km between inland transport and longhaul liner shipping ranges from a factor 5 to a factor 30, further supporting the case tackling inland costs 5 .

Besides cost and revenue considerations, the demand pull force of the market is a main driving force for carriers to integrate their services along the supply chain. Shippers take the global coverage of liner services for granted. What is now focused on is carrier's ability to deliver integrated services. Carriers have to meet shippers' requirements in terms

\footnotetext{
${ }^{5}$ For instance, the freight rates on a port-to-port basis between North Europe and the Far East amount to some $\$ 0.045$ per TEU-km (based on a freight rate of $\$ 800$ and a route length of $10000 \mathrm{~nm}$, THC and additional adjustment factors not included), while inland haulage per truck from north European ports usually ranges from $\$ 0.8$ to $\$ 2$ per TEU-km on an average. By barge the route Antwerp-Emmerich (190 $\mathrm{km}$ ) costs about $\$ 90$ per TEU or $\$ 0.5$ per TEU-km (including handling cost and port dues at inland terminal, but without pre- and endhaul by truck or seaport terminal costs - figures based on CCS Tariff Information System). On longer distances, unit prices per TEU-km for barging are slightly lower.
} 
of frequency, punctuality, reliability and geographical coverage (Slack et al, 1996). The increasingly complex distribution requirements of the customers create significant opportunities for shipping lines. Carriers that have traditionally been concerned only with the transportation of goods from one point to another are now seeking logistics businesses in the area of just-in-time inventory practices, supply chain integration and logistics information system management. With only a few exceptions, however, the management of pure logistics services is done by subsidiaries that share the same mother company as the shipping line but operate independently of liner shipping operations, and as such also ship cargo on competitor lines (Heaver, 2002).

Some shipping lines such as Maersk Sealand have gone rather far in door-to-door services and integrated logistic packages (that is Maersk Logistics), managing the container terminal operation (that is APM Terminals with a network of dedicated terminals that has been opened to third users as well) and inland transport (for example European Rail Shuttle in joint venture with $\mathrm{P} \& \mathrm{O} \mathrm{Nedlloyd}^{6}$ ) and bypassing the freight forwarder by developing direct relationships with the shipper. Other shipping lines stick to the shipping business and try to enhance network integration through structural or ad hoc co-ordination with independent inland transport operators and logistics service providers. A last group of shipping lines combines a strategy of selective investments in key supporting activities (for example agency services or distribution centres) with sub-contracting of less critical services. Shipping lines generally do not own inland transport equipment. Instead they tempt to use trustworthy independent inland operators' services on a (long-term) contract base (see Konings, 1993; Baird and Lindsay, 1996; Graham, 1998; Cariou, 2001; Evangelista and Morvillo, 1998 and Heaver, 2002).

Carriers are confronted with some important barriers to further improve inland logistics. Landside operations are management intensive and generally involve a high proportion of bought-in services. Customer requirements and behaviour often impede carriers from minimizing inland logistics costs. Late bookings for example are costly, because instead of going by train or barge, they must go by truck to catch the ship, for no extra revenue. Moreover, inland movements generate some under-remunerated activities such as the repositioning of empty units, network control and tracking. Other important barriers relate to volume and equipment-type of imbalances, (unforeseen) delays in ports and the inland transport leg as well as the uncertainty of forecasts. Carriers are using IT solutions to face the challenges in inland logistics and to manage global container flows taking into account the effects of global trade imbalances. Moreover, they have learned to lessen equipment surpluses/deficits through container cabotage, inter-line equipment interchanges, chassis pools and master leases ${ }^{7}$. Equipment interchange agreements are often, but not always, maintained among some liner conference members and some

\footnotetext{
${ }^{6}$ ERS operates shuttle trains mainly out of the port of Rotterdam to inland destinations in the Benelux, Germany, Poland, Italy, Belgium, the Czech republic, Hungary and Slovakia. Started at 3 shuttles a week in 1994 ERS now offers 200+ shuttles a week (Van Slobbe, 2002). ERS demonstrates the aim of a number of shipping lines to jointly develop intermodal shuttles on routes where the existing rail products lack a good price-quality relation. Only few deepsea carriers are directly involved in inland navigation. Typically, barge services are maintained by independent barge operators (Charlier and Ridolfi, 1994).

${ }^{7}$ Container cabotage makes it possible to considerably cut the costs related to the repositioning of empty containers: carriers will build up relationships with inland transport operators which move their equipment to where it is needed free of charge. In return the inland operator gets free one-way use of the box. Master leases allow carriers to pick up/drop off equipment at will, placing the repositioning problem to the leasing company. The pick up/drop off charges reflect imbalances.
} 
members of the same strategic alliance (for example New World Alliance). So-called 'grey box' agreements are quite rare: the concept has not proven workable partly because many carriers attach too much attention to company branding via the equipment used.

The formation of global alliances has taken inter-carrier co-operation to new heights, with members sharing inland logistics information, techniques and resources as well as negotiating collectively with suppliers (terminals, rail operators, feeders, barge operators, etc.). By extending to the landside, alliances clearly differ from older forms of operating agreements.

Shipping lines and alliances seek to increase the percentage of carrier haulage on the European continent. The share of carrier haulage presently is about 30 per cent on an average, but large differences can be observed among routes and regions (MDS Transmodal, 1998). A few carriers have succeeded in attaining a high level of carrier haulage. For instance, P\&O Nedlloyd had a carrier haulage percentage in Europe of $49 \%$ in 2002 compared to 45.4 per cent in 1999 (Van Slobbe, 2002). Some other carriers with less experience or interest in European inland transport control less then 10 per cent of inland container movements. If the inland leg is based on merchant haulage than the carrier loses control of and information on its boxes. Carriers are not eager to impose financial penalties for clients that hold boxes too long, as they fear of upsetting and maybe losing the customer.

Carriers have very little room to increase the income out of inland logistics. If the carrier haulage tariffs edge above the open market rates, the merchant haulage option might become more attractive. The resulting competitive pressures partly explain the weak level of price contention between carrier and customer when it comes to charges in the inland leg.

Liner conferences such as TACA (Trans-Atlantic Conference Agreement) have tried to install shared fixing of intermodal inland rates. The European Commission opposes to such practices and decided that the broad block exemption from the usual ban on restrictive agreements given to traditional maritime liner conferences (Council Regulation no. 4056/86) cannot be broadened to include inland operations.

Inland and container logistics thus constitute an important field of action to shipping lines. Lines that are successful in achieving cost gains from smarter management of inland and container logistics can secure an important cost savings advantage. Moreover, because this is difficult to do, it is likely to be a sustainable way of differentiating business from rivals.

\subsection{Changes in liner service network design}

\subsubsection{Limits to the hub-and-spoke principle}

In the last two decades increased cargo availability has made carriers and alliances to reshape their liner shipping networks through the introduction of new types of end-to-end services and pendulum services, especially on the main east-west trade lanes. Pendulum services rely on hub ports that act as turntables between liner services of two different trades and that are served by post-panamax vessels. This kind of liner service design has become popular on high-volume international trade routes such as the trade Europe-Far East- US West coast. As a result the last decade has seen the emergence of a new breed of load centres along the east-west shipping lanes. These sites rely heavily sometimes 
completely on traffic flows that are distantly generated by the interaction of widely separated places and stimulated by the port's en route location or intermediacy.

Much literature has addressed the issue of the hub-feeder system versus direct port calls at continental ports. Some have suggested that the most efficient east/west pattern is the equatorial round-the-world, following the beltway of the world (cf. Ashar 2002 and De Monie, 1997). This service pattern focuses on a hub and spokes system of ports that allows shipping lines to provide a global grid of east/west, north/south and regional services. The large ships on the east/west routes will call mainly at transhipment hubs where containers will be shifted to multi-layered feeder subsystems serving north/south, diagonal and regional routes.

Liner service network design tends to move from a pure cost-driven exercise to a more customer-oriented differentiation exercise, as the optimal network design is not only a function of carrier-specific operational factors, but more and more of shippers' needs (for transit time and other service elements) and of shippers' willingness to pay for a better service. A pattern with the biggest ships possible on high-speed operations between a reduced number of hubs could be interesting from a pure liner network cost perspective, but it has not yet occurred in practice, partly because of customer needs. Hence, the more cost efficient the network becomes from a carrier's perspective, the less convenient that network could be for the shippers' needs in terms of frequency and flexibility. The reality of deepsea operations is that even the largest ships operate on multi-port itineraries. Alliances and consolidation have created multi-string networks on the major trade routes and both shippers and liners are used to it. The multi-loop system of the alliances seems to offer a higher sailing frequency than the single loop-single carrier system. A system of more loops with smaller vessels bears less risk and could therefore eventually turn out to be a cheaper option than running very large vessels on only few loops.

The future spatial development of liner schedules will largely depend on the balance of power between carriers and shippers ${ }^{8}$. The higher the bargaining power of shippers vis-àvis carriers the more pressure for direct calls as this will shift the "cargo follows ship" principle to the "ship follows cargo" principle. Carriers are in the process of reviewing their strategy with respect to liner shipping networks. As liner service network design has become a more customer-oriented differentiation exercise, this could very well introduce a tendency towards less transhipment and more direct port of calls (even for the bigger vessels). Gilman (1999) and Robinson (1998) rightly pointed out that the networks operated by large vessels will continue to be based on end-to-end services. Hub-and-spoke systems are just a part of the overall scene.

\subsubsection{Global coverage}

Notwithstanding existing leader-follower strategies in liner service design, large differences can be observed among container carriers when it comes to the global coverage of liner services (Slack et al, 2001).

\footnotetext{
${ }^{8}$ The attractiveness of the sea-sea hub-and-spoke network to a carrier also partly depends on the actor who will bear the transhipment costs. In the current market environment shippers typically bear these costs via extra THC (Brooks, 2000). Terminal Handling Charges (THC) can be defined as a tariff, charged by the shipping line to the shipper and which (should) cover (part or all of) the terminal handling costs, which the shipping line pays to the terminal operator (Dynamar, 2003). This aspect in the balance of power between shippers and carriers increases the cost advantages of the hubbing option from a carrier's perspective, but may render a hub-and-spoke configuration uncompetitive from a shipper's perspective.
} 
Frémont and Soppé (2003) demonstrate that the alliances mentioned in figure 1 deploy almost 90 per cent of their weekly slot capacity within the triad East Asia, North America and Europe. They have hardly any presence on the secondary routes. Alliances clearly try to build strongholds on the routes they are present and leave other routes to others. This allows the realisation of economies of scale and scope in a global triad-based network.

Notwithstanding the customers' push for global services, a large number of individual carriers typically remain regionally based, offering the bulk of their services on a limited number of trade routes. Asian carriers such as APL, Hanjin, NYK, China Shipping and HMM typically focus on intra-Asian trade, transpacific trade and the Europe - Far East route, partly because of their huge dependence on export flows generated by their Asian home bases. MOL and Evergreen are among the few exceptions frequenting secondary routes such as Africa and South-America. As their individual market shares on these highly competitive triad routes generally are very low, the former carriers lack leadership role in the market and undergo the full effect of market fluctuations. Many of these carriers have allocated 70 to 80 per cent of their slot capacity to a strategic alliance (table 3 ). The alliance structure is crucial to the survival of many of these Asian carriers and open windows of opportunities to a broader global coverage and higher frequencies without significantly increasing the investment requirements.

\begin{tabular}{|c|c|c|c|c|c|c|}
\hline Alliance & $\begin{array}{c}\text { Number of } \\
\text { ships in the } \\
\text { alliance }\end{array}$ & $\begin{array}{l}\text { Total fleet } \\
\text { (number) }\end{array}$ & $\%$ & $\begin{array}{c}\text { Slot capacity in } \\
\text { the alliance } \\
\text { (TEU) }\end{array}$ & $\begin{array}{l}\text { Total slot } \\
\text { capacity }\end{array}$ & $\%$ \\
\hline \multicolumn{7}{|l|}{ Grand Alliance } \\
\hline $\mathrm{P \& O}$ & 39 & 146 & 26.7 & 182550 & 386901 & 47.2 \\
\hline OOCL & 24 & 50 & 48.0 & 119391 & 156016 & 76.5 \\
\hline Hapag Lloyd & 24 & 38 & 63.2 & 115449 & 141717 & 81.5 \\
\hline NYK & 24 & 67 & 35.8 & 96436 & 167001 & 57.7 \\
\hline MISC & 4 & 32 & 12.5 & 16622 & 49808 & 33.4 \\
\hline \multicolumn{7}{|c|}{ Cosco/K-Line/Yangming Alliance } \\
\hline Cosco & 38 & 104 & 36.5 & 154892 & 219324 & 70.6 \\
\hline K-Line & 31 & 58 & 53.4 & 135205 & 174945 & 77.3 \\
\hline Yangming & 16 & 40 & 40.0 & 72867 & 119695 & 60.9 \\
\hline \multicolumn{7}{|c|}{ New World Alliance } \\
\hline $\mathrm{APL}$ & 39 & 76 & 51.3 & 177100 & 240237 & 73.7 \\
\hline Hyundai & 18 & 31 & 58.1 & 99158 & 121890 & 81.4 \\
\hline Mitsui $\quad$ OSK & 16 & 48 & 33.3 & 77410 & 130090 & 59.5 \\
\hline \multicolumn{7}{|l|}{ United Alliance } \\
\hline Hanjin & 32 & 52 & 61.5 & 139205 & 201005 & 69.3 \\
\hline Senator & 28 & 32 & 87.5 & 97566 & 104895 & 93.0 \\
\hline
\end{tabular}

Table 3: The participation of shipping lines in strategic alliances (early 2003)

Source: on the basis of Containerisation International and carrier information

Maersk Sealand, MSC, CMA-CGM and P\&O Nedlloyd are among the truly global liner operators, with a strong presence also in secondary routes. Especially Maersk Sealand has created a balanced global coverage of liner services. The networks of CMA-CGM and MSC differ from the general scheme of traffic circulation through a network of specific hubs (many of these hubs are not among the world's biggest container ports) and a more 
selective serving of secondary markets such as Africa (strong presence by MSC), the Caribbean and the East Mediterranean.

The above reveals the profound differences in service design among shipping lines. Some carriers have clearly opted for a true global coverage, others are somewhat stuck in a triad-based service network forcing them to develop a strong focus on cost bases. In these cases, strategic alliances reveal to be instrumental for the creation of differentiating service attributes vis-à-vis rivals and for creating customer value.

\section{How do container port operators cope with the changing market environment?}

\subsection{Challenges faced by container port operators}

The terminal and stevedoring industry is confronted with bigger and fewer shipping lines demanding more for less. Shipping lines exert growing demands in terms of terminal productivity, priority servicing and flexibility, while at the same time insisting on getting landside costs down (Notteboom, 2002).

The loyalty of a port client cannot be taken for granted. Terminal operators face the constant risk of losing important clients, not because of deficiencies in port infrastructure or terminal operations, but because the client has rearranged its service networks or has engaged in new partnerships with other carriers (Slack et al, 1996). Terminal operators face competition from new entrants, in particular from container carriers, railway companies, logistics companies and investment groups. In Europe for instance, shipping lines have recently entered the market via the development of dedicated terminals at major load centres (table 4). Dedicated terminals are even more widespread in Asia and North America9. Musso et al (2001), Slack and Frémont (2004), Brennan (2002) and Cariou (2003) provide a more in-depth analysis on the issue of dedicated terminals.

\footnotetext{
${ }^{9}$ Drewry Shipping Consultants (2003) collected throughput figures for terminals in which carriers have a non-minority shareholding: Evergreen handled 5.7 million TEU worldwide on its terminals in 2002, Cosco 4.7 million TEU, Hanjin 4.7, APL 4.3, NYK Line 3.5 (including 1.3 million TEU at its subsidiary Ceres Terminals), OOCL 3, NOL 2.5, K-Line 2.2, MSC 2.2, Yang Ming 1.3 and Hyundai 1.1 million TEU. Container shipping lines approach terminal management in a different way: they seek control over berths while other 'pure' terminal operating companies manage multi-user facilities. Many of these liner terminals offer stevedoring services to third carriers as well thereby creating some hybrid form in between pure dedicated facilities and independently operated multi-user facilities.
} 


\begin{tabular}{|c|c|c|}
\hline Shipping line & Terminals & Status \\
\hline Maersk & APM Terminals Rotterdam (100\%) & In operation since 2000 \\
Sealand & In operation \\
(via & APM Sea Terminal Bremerhaven (50\%) & In operation \\
Terminals) & Medcenter - Gioia Tauro (10\%) & In operation \\
& Muelle Juan Carlos I - Algeciras (100\%) \\
& Aarhus (100\%) & In operation \\
\hline APM Contstanza Terminal (100\%) & Operational since 2003 \\
& Dedicated terminal Antwerp (joint venture with & Under development \\
& HesseNoordNatie) & \\
\hline Le Havre (joint-venture with Terminaux De & In operation since 2002 \\
\hline Normandie) & Under construction \\
\hline CP Ships & Altenwerder Terminal - Hamburg (minority & \\
\hline
\end{tabular}

Table 4: Some examples of shipping lines' direct interest in European terminals

\subsection{The emergence of international terminal networks}

In a response to the concentration trend that is unfolding in container shipping, a number of terminal operators have opted for scale increases. This trend is facilitated by the privatisation of port activities. The nature of the container handling business - notably its high fixed costs and lack of service differentiation (except in terms of location) - in theory creates significant opportunities to improve service through co-operation. However, forms of operational co-operation in the market do not come easily and most of the time they end up in mergers or acquisitions (Notteboom, 2002; Musso et al, 2001; Slack and Frémont, 2004).

Many ports around the world are managed based on the landlord concept. Landlord port authorities lease the land to private port operators on the basis of long-term concession agreements. Port authorities have developed specific bidding procedures to grant concessions to the best possible candidates (Goss, 1990). Port authorities can partially shape the entry profile of segments of the local port industry through the bidding procedures used, for example by including some clauses in the concession agreement that should allow the port authority to end the concession in case specific performance measures (for example traffic volumes) are not met by the terminal operator after a specified period of operation. The move towards transparent and open concession procedures results in local terminal operators no longer relying on shelter-based strategies for their survival. At the same time it facilitated the local market entry of global players with deep pockets and specific know how.

These global investors base their investment strategy on exhaustive analyses of profitability and of operational efficiency. The ability to take firm control is also a key issue. Sometimes operators opt for a joint venture with local partners in order to set up successful operations within the confines of the local commercial, economic and governmental environment. Other criteria include a high level of indigenous cargo and a stable political and economic outlook.

P\&O Ports is set to join Hutchison, PSA and APM Terminals at the head of the global port operator league table. These companies have established a truly global presence, collectively operating in over 90 ports throughout 37 different countries. 
In particular China now attracts a lot of attention from global terminal operators - see Wang (2003) for a detailed discussion - as shipping lines are dedicating higher capacities and deploying larger vessels to cope with the increasing Chinese container imports and exports, especially relation to the China-Europe trade (Yap et al, 2003). Chinese ports have become prominent in the ranking of the world's largest container ports (table 5).

\begin{tabular}{|c|c|c|c|c|c|c|c|c|c|}
\hline & & 1985 & 1990 & 1995 & 1998 & 2000 & 2002 & 2003 & $\begin{array}{c}\text { Annual growth } \\
98-02\end{array}$ \\
\hline \multicolumn{10}{|c|}{ Container ports with a throughput exceeding 1.7 million TEU in 2002} \\
\hline Hong Kong & CHINA & 2,29 & 5,10 & 12,55 & 14,58 & 18,10 & 19,14 & 20,45 & $7,8 \%$ \\
\hline Singapore & Singapore & 1,70 & 5,09 & 11,85 & 15,14 & 17,04 & 16,94 & 18,41 & $3,0 \%$ \\
\hline Busan & Korea & 1,16 & 2,35 & 4,50 & 5,75 & 7,54 & 9,54 & 10,37 & $16,5 \%$ \\
\hline Shanghai & CHINA & 0,20 & 0,46 & 1,53 & 3,07 & 5,61 & 8,61 & 11,28 & $45,2 \%$ \\
\hline Kaohsiung & Taiwan & 1,90 & 3,49 & 5,05 & 6,27 & 7,43 & 8,49 & 8,84 & $8,9 \%$ \\
\hline Shenzhen & CHINA & 0,00 & 0,03 & 0,37 & 2,06 & 3,99 & 7,61 & 10,65 & $67,4 \%$ \\
\hline Rotterdam & Netherlands & 2,65 & 3,67 & 4,79 & 6,01 & 6,27 & 6,52 & 7,11 & $2,1 \%$ \\
\hline Los Angeles & USA & 1,10 & 2,12 & 2,56 & 3,38 & 4,88 & 6,11 & 7,18 & $20,2 \%$ \\
\hline Hamburg & Germany & 1,16 & 1,97 & 2,89 & 3,55 & 4,25 & 5,37 & 6,14 & $12,9 \%$ \\
\hline Antwerpen & Belgium & 1,24 & 1,55 & 2,33 & 3,27 & 4,08 & 4,78 & 5,54 & $11,6 \%$ \\
\hline Port Klang & Malaysia & n.a. & 0,47 & 1,13 & 1,82 & 3,21 & 4,53 & 4,80 & $37,3 \%$ \\
\hline LongBeach & USA & 1,14 & 1,60 & 2,84 & 4,10 & 4,60 & 4,52 & 4,66 & $2,6 \%$ \\
\hline Dubai Ports & Jebel Ali & n.a. & 0,92 & 2,07 & 2,80 & 3,06 & 4,19 & n.a. & $12,4 \%$ \\
\hline New York & USA & 2,37 & 1,87 & 2,22 & 2,52 & 3,05 & 3,79 & 4,40 & $12,7 \%$ \\
\hline Qingdao & CHINA & 0,00 & 0,14 & 0,60 & 1,21 & 2,12 & 3,41 & 4,24 & $45,3 \%$ \\
\hline Tokyo & Japan & n.a. & 1,56 & 2,18 & 2,49 & 2,90 & 3,03 & 3,20 & $5,3 \%$ \\
\hline Bremen & Germany & 0,99 & 1,16 & 1,52 & 1,81 & 2,75 & 2,98 & 3,19 & $16,2 \%$ \\
\hline Gioia Tauro & Italy & 0,00 & 0,00 & 0,02 & 2,13 & 2,65 & 2,95 & 3,15 & $9,7 \%$ \\
\hline Manila & Philippines & n.a. & 1,01 & 1,69 & 1,85 & 2,29 & 2,46 & 2,55 & $8,2 \%$ \\
\hline Tanjong Priok & & n.a. & 0,64 & 1,50 & 1,90 & 2,77 & 2,90 & n.a. & $13,2 \%$ \\
\hline Lam Chabang & Thailand & n.a. & n.a. & 0,53 & 1,56 & 2,11 & 2,66 & 3,18 & $17,6 \%$ \\
\hline Tanjung Pelepas & Malaysia & 0,00 & 0,00 & 0,00 & 0,00 & 0,42 & 2,67 & 3,49 & \\
\hline Jakarta & Indonesia & n.a. & n.a. & 1,50 & 1,90 & 2,48 & 2,70 & 2,76 & \\
\hline Tianjin & CHINA & 0,00 & 0,29 & 0,70 & 1,02 & 1,71 & 2,41 & 3,01 & $34,1 \%$ \\
\hline Yokohama & & 1,33 & 1,65 & 2,73 & 2,06 & 2,32 & 2,36 & 2,47 & $3,7 \%$ \\
\hline Algeciras & Spain & 0,35 & 0,55 & 1,15 & 1,83 & 2,01 & 2,23 & 2,52 & $5,5 \%$ \\
\hline Guangzhou & CHINA & 0,00 & 0,08 & 0,51 & 0,85 & 1,43 & 2,17 & 2,76 & $39,1 \%$ \\
\hline Kobe & Japan & 1,86 & 2,60 & 1,46 & 1,86 & 2,03 & 2,38 & 2,39 & $7,0 \%$ \\
\hline Nhava Sheva & & 0,00 & 0,00 & 0,24 & 0,67 & 1,12 & 1,95 & n.a. & $47,7 \%$ \\
\hline Nagoya & Japan & n.a. & 0,90 & 1,48 & 1,43 & 1,90 & 1,93 & 2,05 & $8,7 \%$ \\
\hline Ningbo & CHINA & 0,00 & 0,00 & 0,16 & 0,35 & 0,90 & 1,86 & 2,76 & $106,7 \%$ \\
\hline Xiamen & CHINA & 0,00 & 0,03 & 0,33 & 0,65 & 1,08 & 1,75 & 2,33 & $42,1 \%$ \\
\hline Le Havre & France & 0,57 & 0,86 & 0,97 & 1,32 & 1,46 & 1,72 & 1,98 & $7,6 \%$ \\
\hline \multicolumn{10}{|c|}{ Other Chinese ports } \\
\hline Dalian & CHINA & 0,00 & 0,13 & 0,37 & 0,53 & 1,01 & 1,35 & 1,68 & $39,3 \%$ \\
\hline Jingmen & CHINA & & & & & & 0,49 & 0,74 & \\
\hline Fuzhou & CHINA & 0,00 & 0,00 & 0,00 & 0,06 & 0,34 & 0,48 & 0,55 & $175,6 \%$ \\
\hline \multicolumn{2}{|c|}{ European port system $\left(^{*}\right)$} & 12,36 & 17,00 & 24,75 & 35,06 & 41,20 & 46,50 & & $8,2 \%$ \\
\hline \multicolumn{2}{|c|}{ Chinese mainland, incl. HK $\left({ }^{* \star}\right)$} & 2,49 & 6,25 & 17,13 & 24,38 & 36,30 & 48,81 & 59,71 & $25,0 \%$ \\
\hline \multicolumn{2}{|c|}{ Chinese mainland, excl. HK $\left(^{\star \star}\right)$} & 0,20 & 1,15 & 4,58 & 9,80 & 18,20 & 29,66 & 39,26 & $50,7 \%$ \\
\hline \multicolumn{2}{|c|}{ North-American port system $\left({ }^{* * *}\right)$} & 11,36 & 14,99 & 20,90 & 25,35 & 29,73 & 31,00 & & $5,6 \%$ \\
\hline
\end{tabular}

Table 5: Container throughput in world container ports (million TEU)

Notes: $(*)$ total for 47 container ports (port authorities figures); $(* *)$ total for Chinese container ports featuring in this table (with or without Hong Kong); (***) total for 35 container ports, 2002 is an estimate (AAPA figures)

Source: ITMMA-UA based on statistics Ministry of Communications PRC, AAPA and port authority data

Pursuing organic growth is generally the lowest risk/lowest reward strategy available to container terminal operators. It is only by pursuit of higher risk growth strategies that today's global operators have progressed from being single location/regional players into the global market. In developing a global expansion strategy, HPH, PSA Corp, APM 
Terminals and P\&O Ports try to keep a competitive edge by building barriers to prevent competitors entering their domains or against them succeeding if they do. These barriers are partly based on the building of strongholds in selected ports around the world and on advanced know how on the construction and management of container terminals. The scale of operations has created deep pockets or substantial surplus resources that allow them to withstand an intensive competitive war and that enable them to financially outperform rival companies in case of bidding procedures for new terminal operations. The deep pockets are used to move resources wherever they are necessary either to preserve their own interests or tackle competition. In the current market situation, the global players seem to be best placed to meet the high capital requirements to cover initial investments in a terminal of a reasonable scale.

For example, PSA Corporation first built a stronghold at its home base Singapore before taking the step towards global scale and coverage. The critical mass and its focused strategy at Singapore enabled PSA Corp. to develop exceptional competencies in terminal handling. Once the company established itself as an international benchmark, the company's ambitions went global through a mixed strategy of organic growth (new terminals) and acquisitions (for example HesseNoordNatie in 2002) backed up by a sound financial status. This development was accelerated by increased competition at its Singapore terminals, not at the least from newcomer Tanjung Pelepas - Malaysia, and with it less opportunities for internal growth.

Smaller terminal operators have not been successful in neutralising the power of these giants. Many of them avoid direct competition by concentrating on market niches, for example on the shortsea market. Over the course of the next five years the gap between the four largest companies and the remaining global operators (many of which are carrierbased operators) is therefore set to widen further. By 2008, the top four operators will control over one third of total world container port capacity (Drewry Shipping Consultants, 2003). This figure is set to continue increasing if the current level of acquisition activity continues.

Market concentration is very evident when looking at the regional scale, although systems used might differ regionally based on factors embedded in institutional and governance aspects that are regionally bound. Slack and Frémont (2004) demonstrate that the non-carrier based global terminal operators have not been able to penetrate the North American stevedoring market, while at the same time they have expanded business considerably in Asia and Europe. A lack of liberalisation in the port sector, dock labour problems and a strong preference towards liner-operated terminals to secure port cargo (port concern) and space (carrier concern) are the main reasons for the specific North American situation.

In Europe, the top six leading operators handled nearly 70 per cent of the total European container throughput in 2002 compared to 53 per cent in 1998, illustrating the mature and consolidated nature of this market (table 6). These figures are expected to rise as consolidation still continues and as the big players plan new massive terminals: PSA Corp. in Flushing, Antwerp and Sines, P\&O Ports along the Thames (London Gateway project), Eurogate in Wilhelmshaven and HPH at Bathside Bay (Harwich - UK). The consolidation trend in European container handling leads to some controversy (Notteboom, 2002). On the one hand, the extensive terminal networks are often considered as an effective means to counterbalance the power of carrier combinations in liner shipping, to realise economies of scale and to optimise the terminal function within logistics networks. 
At the same time, however, the industry structure has become sufficiently concentrated to raise a fundamental question about whether market forces are sufficient to prevent the abuse of market power. EU competition regulations have already affected Hutchison's expansion within North Europe, and it is likely that any future moves by PSA Corp or P\&O Ports will also be carefully scrutinised by the regulatory authorities. Regulatory bodies aim to encourage cost reductions and at the same time avoid the abuse of oligopolistic market powers.

\begin{tabular}{|c|c|c|c|c|}
\hline & $\begin{array}{l}\text { Worldwide } \\
\text { throughput } \\
2002\end{array}$ & $\begin{array}{l}\text { European } \\
\text { throughput } \\
2002\end{array}$ & $\begin{array}{l}\text { European } \\
\text { throughput } \\
1998\end{array}$ & $\begin{array}{l}\text { Annul growth } \\
\text { Erope } 98-02\end{array}$ \\
\hline $\begin{array}{l}\text { Hutchison Port Holding (HPH) - China } \\
\text { Felixstowe(UK), Thamesport (UK), Herwich (UK), ECT-Ratterdam(the Netherlands) }\end{array}$ & 36.70 & 6.90 & 7.75 & $-27 \%$ \\
\hline $\begin{array}{l}\text { PSA Corp-Singapore } \\
\text { Vdtri-Genca(Italy), Sines (Patuga), VECON-Venice(Italy), } \\
\text { HesseNbordNatieAntwerp/Zeebrugge(Belgium) }\end{array}$ & 26.20 & 5.44 & 0.60 & $201.7 \%$ \\
\hline $\begin{array}{l}\text { APMTerminals - Dermark } \\
\text { Bremerhaven (Germeny), Ratterdam(the Netherlands), Ageciras (Spain), } \\
\text { Giaia Tauro (ttaly, 10\% stake) }\end{array}$ & 17.20 & 3.24 & 1.00 & $56.0 \%$ \\
\hline $\begin{array}{l}\text { P\&OPorts-UK } \\
\text { Antwerp (Belgium), MerseilleleHeHe(France, jaint-venture OMACGM), } \\
\text { Southampton(UK), Tilbury (UK) }\end{array}$ & 1280 & 276 & 1.25 & $30.2 \%$ \\
\hline $\begin{array}{l}\text { Eurogate-Germany } \\
\text { Eurdka-Hamburg (Germany), BLG-Bremen (Germany), LaSpezia(Italy), CCT-Cagiai (Italy) } \\
\text { Medbenter-GiaiaTaro(Italy), Lisoont-Lisbon(Partuga), Livomo(Italy), Salemo(Italy) }\end{array}$ & 9.59 & 9.59 & 5.73 & $16.8 \%$ \\
\hline $\begin{array}{l}\text { HLA-Germany } \\
\text { Hemburg (Germeny) }\end{array}$ & 4.00 & 4.00 & 235 & $17.6 \%$ \\
\hline Total of six major European container terminals operating companies & 106.49 & 31.93 & 18.68 & $17.7 \%$ \\
\hline Grand total & 275.00 & 46.50 & 35.06 & $8.2 \%$ \\
\hline Share 6 operators in grand total & $38.7 \%$ & $68.7 \%$ & $53.3 \%$ & \\
\hline
\end{tabular}

Table 6: Global terminal operators' presence in the European container port system

Note: figures include all terminals in which non-minority shareholdings were held.

Source: based on terminal operator data and Drewry Shipping Consultants (2003)

The response of the port sector to the shipping sector is inherently complementary to the changes in the shipping world. At the end a network of efficient seaports is needed, which for the sake of global welfare might lead to an efficient maritime transport system. This implies that both shipping lines and terminal operators parties should be in a position to work in similar working conditions.

\subsection{Integration along the supply chain}

Terminal operators are well aware of the fact that the transport chain is viewed as a totally integrated system. The leading terminal operating companies have developed diverging strategies towards the control of larger parts of the supply chain.

The door-to-door philosophy has transformed a number of terminal operators into logistics organisations. The services offered include warehousing, distribution and low-end value-added logistical services (for example customising products for the local markets). The recent focus of Hutchison on inland logistics in China is an example. 
Especially German terminal operators are directly involved in intermodal rail transport (Notteboom, 2002). In recent years, Eurogate has been particularly successful in creating a European landbridge beween its German and Italian load centres. This Hannibal express, a north-south rail corridor that connects the intermodal services of subsidiary Sogemar in Italy to the shuttle network of boxexpress.de in Germany, offers carriers more flexibility in liner service design and transit times (Alberghini, 2002). Some terminal operators have set up road haulage companies or operate own feeder services. Finally, many terminal operators have integrated inland terminals in their logistics networks (see table 7 for the European case). These inland terminals in many cases serve as extended gates for deepsea terminals.

ECT of Rotterdam operates a rail terminal in Venlo (since 1982) and trimodal terminals in Willebroek (TCT Belgium - since 1999) and Duisburg (also since 1999, $(*)$ ). ECT plans to build a barge terminal in Venlo (Venlo Barge Terminal). ECT, Rotterdam Municipal Port Management and the forwarding company Eurotrafo have a joint share of 53 per cent in a network of rail terminals in the Czech Republic and Slovakia operated by CSKD-Intrans.

Seaport Terminals/Katoen Natie has invested in an inland terminal network in the Benelux (for example in Wielsbeke and Terneuzen).

The combination P\&O Ports/Logport has developed a logistics zone and trimodal terminal on the site of Hafen Rheinhausen in Duisburg.

Gerd Buss of Hamburg is an indirect shareholder of DCH (Düsseldorfer Container-Hafen).

Unikai Hafenbetrieb, a subsidiary of HHLA (Hamburger Hafen- und Lagerhaus) recently sold its river container terminals in Wörth (Middle Rhine) and Ottmarsheim (Upper Rhine) to Rhenus.

CSX World Terminals is partner in the Rhine terminal CTG - Germersheim.

\section{Table 7: The involvement of terminal operators in north European inland terminals}

Note: (*) The ECT terminal in Duisburg merged in 2001 with the neighbouring DeCeTe terminal. ECT has a stake of 27 per cent in the new terminal company that operates under the name DeCeTe.

Source: Notteboom (2002)

Not every terminal operator is integrating by acquiring or setting-up separate companies or business units. In many cases, an effective network integration is realised through better co-ordination with third-party transport operators or logistics service providers.

\section{Conclusions}

Shipping lines and terminal operators face increasingly turbulent, fast-changing and uncertain situations. The port and shipping markets are not stable any longer because the forces at work in the environment are rapidly changing. Technological advances, deregulation, logistics integration and associated new organisational structures, in particular, are constantly reshaping the port and maritime industries, and companies are busily trying to disrupt the status quo rather than preserve it. 
Shipping lines have long believed to outperform rivals by deploying larger vessels. This unilateral focus on operational costs at sea proved to have its limitations. The essence of shipping lines' existence is gradually shifting from pure shipping operations to integrated logistics solutions. Each carrier tries to give a meaningful answer to this paradigm shift. Through various forms of integration along the supply chain, shipping lines are trying to generate revenue, to streamline sea, port and land operations and to create customer value. For the time being, container terminal operators are mainly focused on increasing the scale of operations. Global terminal operators clearly have shifted their mindset from a local port level to a port network level, albeit that the terminal network effects still have to be exploited to the full. There even exist evidence of increasing logistics integration with inland terminals, hinterland transportation and broader logistics services. Also here, the paradigm shift is at the core of operators' refocusing.

Individual terminal operators and shipping lines might walk different paths on a quest for higher margins and increased customer satisfaction. And more than once they change paths as the bases of competitiveness in the highly competitive markets are likely to erode sooner or later. Port and maritime companies try to sustain a competitive edge by building barriers to prevent competitors from entering their domains. New entrants seek to minimise these kinds of entry barriers, for example by entering from a contiguous market in which they have already gained some knowledge and experience, or entering on a small scale. As such, bases of competitiveness are likely to escalate in the port and maritime industries as companies seek to make different market moves, for example by entering new markets or building strongholds in existing markets, and building different barriers.

\section{$5 \quad$ References}

Alberghini, G. (2002) The Potential Benefits of a European Intermodal Network for the Transport of Maritime Containers, ITMMAPS-conference, Antwerp, unpublished paper.

Ashar, A (2002) "Revolution Now," Containerisation International, January.

Baird, A.J. and Lindsay, A.J. (1996) Strategic Choice in the Global Container Shipping Industry: A Resource-Based Approach, IAME '96 Conference, International Association of Maritime Economists, Vancouver.

Baird, A.J., (2000) "Port Privatisation: Objectives, Process and Financing," Ports and Harbors, 45:14-19.

Brennan, J.R. (2002) “Brave New World,” Containerisation International, 35: 39-41.

Brooks, M. (2000) Sea Change in Liner Shipping: Regulation and Managerial DecisionMaking in a Global Industry. Pergamon.

Brooks, M. (2001) Good Governance and Ports as Tools of Economic Development: Are They Compatible? Proceedings of the IAME2001 Conference, Hong Kong, 1-19.

Cariou, P. (2001) "Vertical Integration Within the Logistic Chain: Does Regulation Play Rational? The Case for Dedicated Container Terminals" Transporti Europei, 7: 37-41. 
Cariou, P. (2003) Dedicated Terminals in Container Ports: A Cost-Benefit Analysis, Research Seminar: Maritime Transport, Globalisation, Regional Integration and Territorial Development, Le Havre.

Charlier, J. and Ridolfi, G. (1994) "Intermodal Transportation in Europe: Of Modes, Corridors and Nodes," Maritime Policy and Management, 21: 237-250.

Chinnery, K. (1999) "Global Alliances in Container Shipping and Their Potential Effects on Ports," Ports and Harbors, 44: 20-22.

Christopher, M. (1992) Logistics and Supply Chain Management: Strategies for Reducing Costs and Improving Services, Pitman Publishing, London.

Cullinane, K., Khanna, M. and Song, D.-W. (1999) "How Big is Beautiful: Economies of Scale and the Optimal Size of Containership, Liner Shipping: What's Next?" Proceedings of the 1999 IAME conference, Halifax, 108-140.

De Monie, G. (1995) Privatisation of Port Structures. Ports for Europe Conference. Brugge, Europe College.

De Monie, G. (1997) The Global Economy, Very Large Containerships and the Funding of Mega-Hubs, Port Finance Conference, London.

Drewry Shipping Consultants (2001) Post-Panamax Containerships - The Next Generation. London.

Drewry Shipping Consultants (2003) Annual Review of Global Container Terminal Operators. London.

Dynamar (2003) Terminal Handling Charges: A Bone of Contention, Dynamer, Alkmaar, 57.

Evangelista, P. and Morvillo, A. (1998) Logistics Integration and Co-Operative Strategies in Liner Shipping: Some Empirical Evidence, paper presented at $8^{\text {th }}$ World Conference on Transport Research, Antwerp, July 1998.

Everett, S. (1996) Corporatisation Strategies in Australian ports: Emerging Issues, IAME 1996 Conference - Shipping, Ports and Logistics Services: Solutions for Global Issues. Vancouver: IAME.

Fremont, A. and Soppe, M. (2003) The Service Strategies of Liner Shipping Companies, Research Seminar: Maritime Transport, Globalisation, Regional Integration and Territorial Development, Le Havre.

Gilman, S. (1999) "The Size Economies and Network Efficiency of Large Containerships," International Journal of Maritime Economics, 1: 1.

Goss, R. (1990) "Economic Policies and Seaports - Part 3: Are Port Authorities Necessary?” Maritime Policy and Management, 17: 257-271. 
Graham, M.G. (1998) "Stability and Competition in Intermodal Container Shipping: Finding a Balance," Maritime Policy and Management, 25: 129-147.

Hastings, P. (1997) "Lines Seek New Savings on Inland Costs," Cargo Today, 3: 1:5-9.

Heaver, T., Meersman, H., Moglia, F., Van de Voorde, E. (2000) "Do Mergers and Alliances Influence European Shipping and Port Competition?" Maritime Policy and Management, 27: 363-373.

Heaver, T. (2002) "The Evolving Roles of Shipping Lines in International Logistics," International Journal of Maritime Economics, 4: 210-230.

Konings, R. (1993) "De Rol Van de Zeerederij in Het Achterlandvervoer van Containers," Tijdschrift Vervoerswetenschap, 29: 225-233.

Lim, S.-M. (1998) "Economies of Scale in Container Shipping," Maritime Policy and Management, 25: 361-373.

Martin, J. and Thomas, B.J. (2001) "The Container Terminal Community," Maritime Policy and Management, 28: 279-292.

McKinnon, A. (2001) "Integrated Logistics Strategies," in: Brewer, et. al., Handbook of Logistics and Supply Chain Management, Elsevier Science.

Midoro, R. and Pitto, A. (2000) "A Critical Evaluation of Strategic Alliances in Liner Shipping," Maritime Policy and Management, 27: 31-40.

MDS Intermodal (1998) The European Container Freight Market: Containers Inland. Chester.

Musso, E., Ferrari, C. and Benacchio, M. (2001) Co-Operation in Maritime and Port Industry and Its Effects on Market Structure, paper presented at WCTR Conference, Seoul.

Notteboom, T., Winkelmans, W. (2001) "Reassessing Public Sector Involvement in European Seaports," International Journal of Maritime Economics, 2: 242-259.

Notteboom, T. and Winkelmans, W (2001b) "Structural Changes in Logistics: How Do Port Authorities Face the Challenge?" Maritime Policy and Management, 28: 71-89.

Notteboom, T. (2002) "Consolidation and Contestability in the European Container Handling Industry," Maritime Policy and Management, 29: 257-269.

Ocean Shipping Consultants (1997) Global Container Port Demand and Prospects: Throughput, Competition, Investment, Capacity Utilization and Forecasts, OSC, Chertsey.

Ocean Shipping Consultants (2003) World Containerport Outlook to 2015, OSC, Chertsey.

Robinson, R. (1998) “Asian Hub/Feeder Nets: The Dynamics of Restructuring," Maritime Policy and Management, 25: 21-40. 
Robinson, R. (2002) "Ports as Alements in Value-Driven Chain Systems: The New Paradigm," Maritime Policy and Management, 29: 241-255.

Ryoo, D.K. and Thanopoulou, H.A. (1999) "Liner Alliances in the Globalisation Era: A Strategic Tool for Asian Container Carriers," Maritime Policy and Management, 26: 349.

Slack, B., Comtois, C. and Sletmo, G. (1996) "Shipping Lines as Agents of Change in the Port Industry," Maritime Policy and Management, 23: 289-300.

Slack, B., Comtois, C., McCalla, R.J. and Guy, E. (2001) Global Reach: The Evolving Pattern of Container Shipping Networks, paper presented at World Conference on Transport Research, Soeul, July 2001.

Slack, B., McCalla, R.J., Comtois, C. (2002) Logistics and Maritime Transport: A Fundamental Transformation, paper presented at Annual Meeting of the American Association of Geographers, Los Angeles, March 2002.

Slack, B., Comtois, C., McCalla, R.J. (2002) "Strategic Alliances in the Container Shipping Industry: A Global Perspective," Maritime Policy and Management, 29: 65-75.

Slack, B. and Frémont, A. (2004) The Transformation of Port Terminal Operations - From the Local to the Global, unpublished paper.

UNCTAD (2002) Review of Maritime Transport, Geneva.

Van Slobbe, R. (2002) Larger Volumes, Increasing Scale, Environmental Aspects and Road Congestion Require Intermodal Solutions, ITMMAPS-conference, Antwerp.

Wang, J. (2003) "Port Governance in China, A Review of Policies in an Era of Internationalising Port Management Practices," Transport Policy, forthcoming.

Yap, W.Y., Lam, J.S.L. and Notteboom, T. (2003) "Developments in Container Port Competition in East-Asia," Proceedings of IAME 2003 Conference, International Association of Maritime Economists, Busan (South Korea), 715-735. 